\title{
Confirmatory Factor Analysis Of Indonesian Employment Seen From Industrial Economic Views
}

\author{
Tiur malasari siregar ${ }^{1 *}$, Irsad Lubis ${ }^{2}$ \\ 1,2Department of Economic Development, Universitas Sumatera Utara, Indonesia \\ *tiurmalasarinew2019@gmail.com ${ }^{1}$ \}
}

\begin{abstract}
Labor plays an important role in the establishment of a company. The number of companies or industries is also a driver of economic growth. This study is aimed at analyzing the influence of the labor force, employment opportunities, education level, employment status, and unemployment rate in Indonesia in 2002-2018. The results obtained in this study are stated that the labor force variable has a positive and significant effect on the labor industry in Indonesia. Absorption of industrial labor in Indonesia is strongly influenced by the labor force, employment opportunities, education status of employment status, and unemployment rate also have a positive and significant impact on the absorption of industrial labor in Indonesia.
\end{abstract}

Keywords: Labor, Industrial Economy, Labor Force.

\section{Introduction}

According to UU No. 5 of 1984 concerning Industry, the industry is an economic activity that processes raw materials, raw materials, semi-finished goods, and finished goods into goods with a higher value for their use, including engineering design and industrial engineering activities. The industry is generally known as the next chain of efforts to meet the needs (economy) associated with the earth, namely after agriculture, plantations, and mining, which are closely related to land.

Labor plays an important role in the establishment of a company. In a company, humans need to communicate with each other to achieve something that is their goal. Similar to companies, companies also have the goal of wanting to get as much profit as possible. Labor problems are problems that will be faced by every company. Industries that rely on talent, skills, and creativity are the basic elements of every individual. Large and modern companies have used machines or automated devices for computers, but the people who control all the running of these machines are human.

As stated in Square [1] that small industries play a large role in the absorption of labor, in labor absorption is influenced by several factors, one of which is the number of industries and the value of production produced by the industry.

As said [2] that efforts to expand industrial activities to increase labor demand are inseparable from the factors that influence it, such as the number of business units, investment value, and production value. One way to expand industrial activities is through the development of labor-intensive industries, namely small and medium industries. 
The number of workers in Indonesia reached 131.55 million, with the absorption of 124.54 million or reaching 94 percent. Even though it is seen, a good problem arises because when viewed from the labor force, around 57 percent of Indonesian people who work have junior high school education and below. Based on the 2018 national labor force survey (Sakernas) reported by Indef, 14.93 percent of workers came from those with less than elementary school education, 24.55 percent of elementary school graduates, and 17.98 percent of junior high school graduates. This figure is even sadder when seeing those who graduated from vocational high school, high school, even diplomas, and universities get lower employment rates, respectively 10.72 percent, 11.76 percent, 2.8 percent, and 9.45 percent [3].

The labor force is the potential of a country, but not all workers are absorbed by number of available jobs. This situation led to unemployment. Efforts to reduce unemployment continue to be made, to avoid various risks. Data on the August 2017 Labor Force from the Central Statistics Agency (BPS) recorded that there were around 7 million unemployed people, out of a total of 128 million workforces. More specifically by age group, the largest workforce in Indonesia is the people aged 35-39 years. The labor force of this age group reaches 17.6 million people. The second-largest position is occupied by those aged 30 34 years, with a total of 15.5 million people. Thus, the situation of the labor force in Indonesia - referring to the age group, is the productive age group, which is at the same time as the main worker group. That is, this labor force has the potential to be a driving force in the production of goods and services.

The low level of education and the mismatch of expertise and skills possessed by job seekers with the qualifications needed by companies triggered the low absorption of Indonesian workers. Following is an explanation of the distribution of Indonesian workers; there is a pretty fundamental change in the Indonesian workforce when viewed in terms of quality. Employment absorption in Indonesia is still very low, with $32 \%$ of the $2,381,841$ registered job vacancies apparently unable to be filled by job seekers. This is triggered by the low level education and the incompatibility of expertise and skills possessed by job seekers with the qualifications needed by the company.

Table 1. Level of Education of Indonesian Workers 2000 - 2010

\begin{tabular}{|l|l|l|l|l|l|l|l|l|l|l|l|}
\hline TINGKAT PENDIDIKAN TENAGA KERJA INDONESIA TAHUN $2000-2010$ \\
\hline Pendidikan & 2000 & 2001 & 2002 & 2003 & 2004 & 2005 & 2006 & 2007 & 2008 & 2009 & 2010 \\
\hline Kurang Terdidik & $77,7 \%$ & $77,8 \%$ & $77,7 \%$ & $76,8 \%$ & $76,3 \%$ & $75,8 \%$ & $75,6 \%$ & $74,9 \%$ & $73,5 \%$ & $71,1 \%$ & $69,4 \%$ \\
\hline$\geq$ Tamat SD & $62,1 \%$ & $61,2 \%$ & $60,9 \%$ & $56,7 \%$ & $56,5 \%$ & $56,2 \%$ & $55,6 \%$ & $54,6 \%$ & $54,5 \%$ & $52,6 \%$ & $50,4 \%$ \\
\hline SLTP & $15,6 \%$ & $16,6 \%$ & $16,7 \%$ & $20,1 \%$ & $19,8 \%$ & $19,5 \%$ & $20,0 \%$ & $20,3 \%$ & $19,0 \%$ & $18,5 \%$ & $19,1 \%$ \\
\hline Terdidik & $22,3 \%$ & $22,2 \%$ & $22,3 \%$ & $23,2 \%$ & $23,7 \%$ & $24,2 \%$ & $24,4 \%$ & $25,1 \%$ & $26,5 \%$ & $28,9 \%$ & $30,6 \%$ \\
\hline SMU/SMK & $17,9 \%$ & $17,4 \%$ & $17,6 \%$ & $18,6 \%$ & $18,4 \%$ & $18,8 \%$ & $18,8 \%$ & $19,1 \%$ & $20,2 \%$ & $21,8 \%$ & $22,9 \%$ \\
\hline Akademi/Dipl. & $2,2 \%$ & $2,2 \%$ & $2,1 \%$ & $1,9 \%$ & $2,2 \%$ & $2,3 \%$ & $2,3 \%$ & $2,5 \%$ & $2,6 \%$ & $2,7 \%$ & $2,8 \%$ \\
\hline \begin{tabular}{l} 
Universitas \\
\hline
\end{tabular} & $2,2 \%$ & $2,6 \%$ & $2,6 \%$ & $2,7 \%$ & $3,0 \%$ & $3,1 \%$ & $3,3 \%$ & $3,6 \%$ & $3,7 \%$ & $4,4 \%$ & $4,8 \%$ \\
\hline
\end{tabular}

Workers with a junior high school education or lower are classified as a less educated labor force, while workers who have at least successfully completed education at the high school / vocational level are classified as an educated labor force.

Based on this data, the proportion of educated workforce continues to increase from $22.3 \%$ in 2000 to $30.6 \%$ in 2010 . Furthermore, the table above shows that this increase occurred both in those who graduated from high school / vocational school or college graduates (including programs diploma). 
On the contrary, the decrease in the proportion of workers who are less educated is driven by a decrease in the proportion of those who have only completed primary school (SD) or lower, while the proportion of those who have only completed junior high school tends to continue to increase. This situation is the impact of government policies in the field of basic education in the form of fee waivers for elementary school and junior high school (SLTP) levels.

A labor force that is equipped with skills, productive, and can have a career in employment if 38 percent of the 124 million workforces in Indonesia is apparently still dominated by elementary school graduates. In fact, the government wants Indonesian workers to be ready to face the Industrial Revolution Era 4.0.

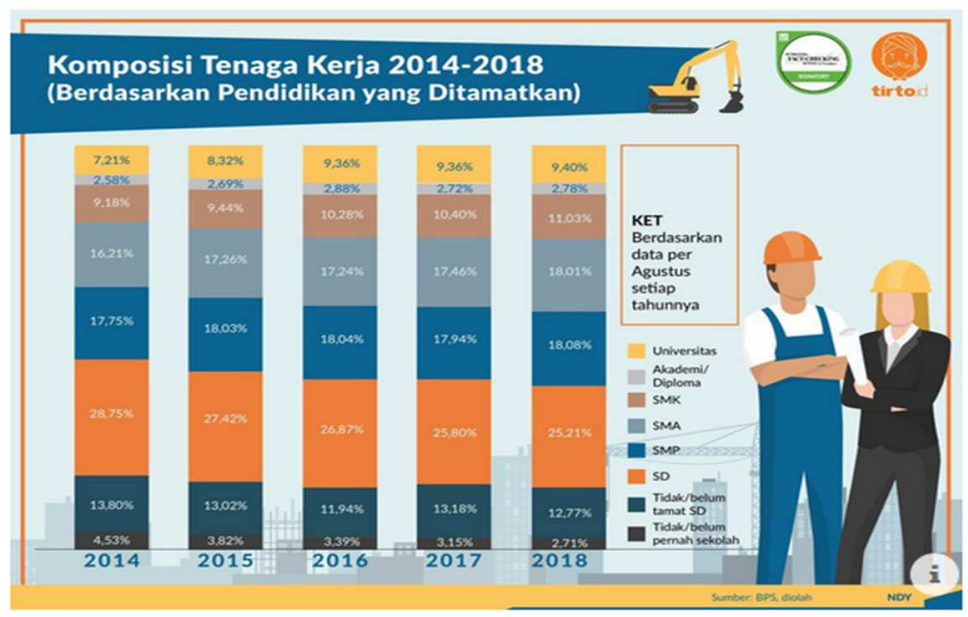

Fig 1. Labor Composition 2014 - 2018

Based on the highest level of education completed, elementary school graduates dominate the share of Indonesian labor. In the period 2014 to 2018, at least a quarter of the labors were elementary school graduates. In 2014, there was 28.75 percent of elementary school graduates. The number continues to decline until it reached 25.21 percent in 2018 . The second-largest contributor is the junior high school graduate. The composition of the labor who are junior high school graduates ranges from 17-18 percent annually, when the total composition between elementary and junior high school graduates reaches 43 percent. However, the combined group of high school and equivalent graduates (SMK) also belongs to the majority because it controls more than a quarter of the labor. In 2014, the combined high school and vocational school controlled 25.39 percent of the labor. With an upward trend in the high school and vocational groups, the combined portion of the group also went up. As of 2018, a combination of high school and vocational graduates controlled 29.04 percent of the share of Indonesian workers. Meanwhile, workers who have never attended school and did not complete elementary school contribute 15 to 18 percent of labor annually with a downward trend. Interestingly, SMK graduates who are staying ready to enter the labor even contribute fewer workers than elementary and junior high school graduates. Although experiencing an upward trend, the highest number had only reached 11.03 percent in 2018. This lower contribution compared to other groups is quite reasonable because the share of the labor force of SMK graduates also ranges from 9-11 percent of the total workforce over the past five years. 


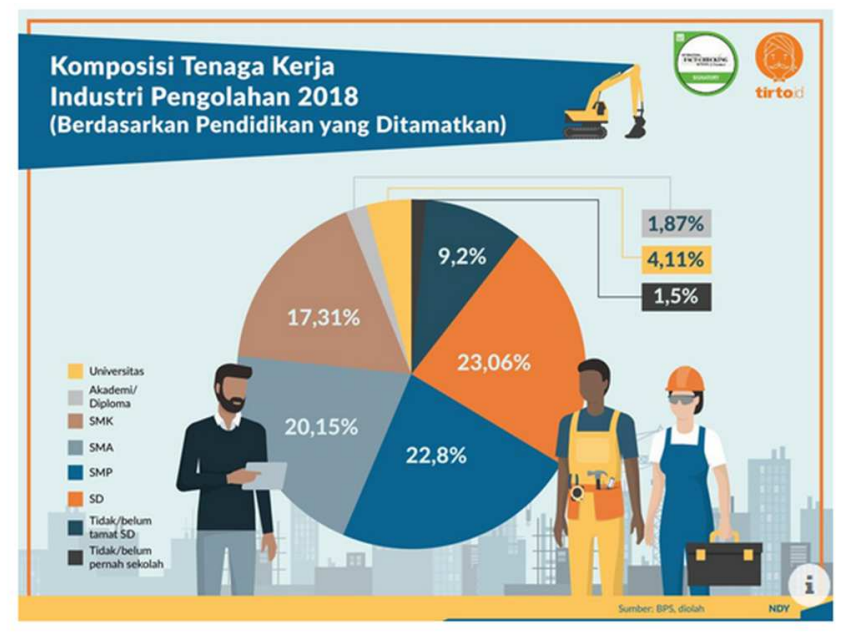

Fig 2. The composition of the labor in 2018

Junior high school graduates are the second largest contributor to the manufacturing or manufacturing industry, with a composition of 22.8 percent or around 4.16 million workers. When combined, elementary and junior high school graduates control almost half the share of the workforce in the manufacturing sector with 45.86 percent. Vocational High School graduates who are prepared to work in the industry only contribute 17.31 percent or 3.16 million workers. The contribution is relatively small compared to the lower education.

The economic slowdown (2011-2015) when the commodity boom of the 2000s suddenly ended amid a global economic slowdown. This is another sign that the Indonesian economy is too dependent on commodity prices (which are volatile). Therefore, President Joko Widodo's efforts to reduce Indonesia's dependence on (raw) commodity exports are valued and should lead to a structurally stronger economy in the future. This should also have a positive impact on unemployment in Indonesia.

Unemployment in Indonesia (Relative):

\begin{tabular}{|lcccccccc|}
\hline & 2013 & 2014 & 2015 & 2016 & 2017 & 2018 \\
\hline $\begin{array}{l}\text { Unemployment } \\
\text { (\% of total labor) }\end{array}$ & 6.2 & 5.9 & 6.2 & 5.6 & 5.5 & 5.1 & \\
\hline & 2006 & 2007 & 2008 & 2009 & 2010 & 2011 & 2012 \\
\hline $\begin{array}{l}\text { Unemployment } \\
\text { (\% of total labor) }\end{array}$ & 10.3 & 9.1 & 8.4 & 7.9 & 7.1 & 6.6 & 6.1
\end{tabular}

Source: Statistics Indonesia (BPS)

If we look at unemployment in urban and rural areas in Indonesia, we can see that unemployment is - significantly - higher in urban areas compared to rural areas. Equally interesting is that the gap between urban and rural unemployment has widened over the past four years because rural unemployment has declined faster than urban unemployment.

The Ministry of Industry projects that the demand for labor in the industrial sector will rise to exceed $8 \%$ until 2035 . This increase is spread across all manufacturing sub-sectors, such as the food and beverage, metal, textile and clothing, and automotive industries. "The 
high labor demand is in line with the entry of a number of investments in Indonesia and the government's efforts to increasingly encourage the industrial sector to continue to expand, both in order to meet the domestic and export markets," said Coordinator of the Industrial Human Resources Development Agency (BPSDMI) of the Ministry of Industry, Mujiyono. Ministry of Industry page, Jakarta, Wednesday [5]. Based on the introduction above, it is important to study how the industrial labor in Indonesia and the factors that affect the labor force, employment opportunities, education level, employment status, and the unemployment rate in the work industry.

\section{Research Methods}

This analysis uses research objects in the Indonesian industry. And is a type of quantitative descriptive (secondary) research, and the data used comes from websites and books in numbers at the Central Statistics Agency. In this study, the number of samples used was labor data for 2002-2018 [6]. The operational definition of the independent variable is Industrial Labor from 2002 - 2018.

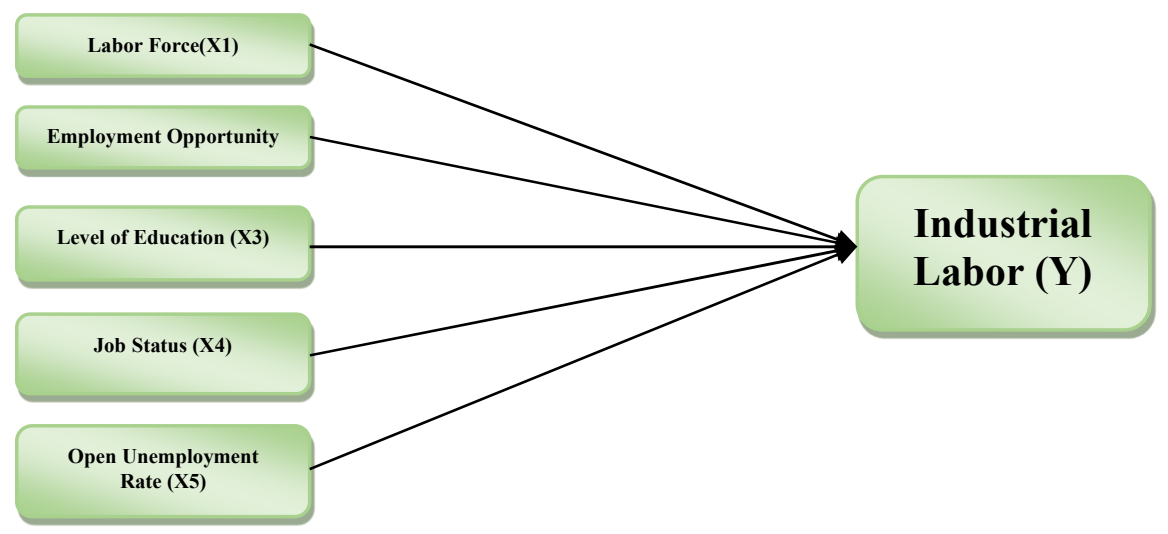

Fig 3. CFA Conceptual Framework

This mini-research uses the Confirmatory Factor Analysis (CFA) method and Multiple Linear Regression. Confirmatory Factor analysis (CFA) [7].

To answer the first hypothesis, the Confirmatory Factor Analysis (CFA) method is used. CFA aims to find a way to summarize the information contained in the original (initial) variable into a set of new dimensions or factors by the formula:

$$
\begin{aligned}
& \mathrm{Xi}=\mathrm{Bi} 1 \mathrm{~F} 1+\mathrm{Bi} 2 \mathrm{~F} 2+\mathrm{Bi} 3 \mathrm{~F} 3+\ldots \ldots \ldots \ldots \ldots . .+\mathrm{Vi} \mu \mathrm{i} \\
& \mathrm{Xi} \quad=\mathrm{Bi} 1 \mathrm{~F} 1+\mathrm{Bi} 2 \mathrm{~F} 2+\mathrm{Bi} 3 \mathrm{~F} 3+\mathrm{Bi} 4 \mathrm{~F} 4+\mathrm{Bi} 5 \mathrm{~F} 5 \\
& \mathrm{TKIN}=\mathrm{b} 1 \mathrm{AK}+\mathrm{b} 2 \mathrm{KK}+\mathrm{b} 3 \mathrm{TP}+\mathrm{b} 4 \mathrm{SP}+\mathrm{b} 5 \mathrm{TPT}
\end{aligned}
$$

Explanation :

$\mathrm{Xi}=$ Standardized $\mathrm{i}$-th variable

$\mathrm{Bij}=$ Partial regression coefficient for variable $\mathrm{i}$ on the $\mathrm{j}$-th common factor

$\mathrm{Fj}=$ The i-common factor 
$\mathrm{Vi}=$ Standardized regression coefficients for $\mathrm{i}$-th variables on $\mathrm{i}$-unique factors $\mu \mathrm{i}=$ Variable unique factor

\section{Results and Discussion}

Confirmatory Factor Analysis (CFA) Results

To analyze the research data, the researcher conducts and applies a quantitative analysis method by managing the data and then interpreting it so that a true picture of the problem under study will be obtained. Then a factor analysis is performed, which aims to find a way to summarize the information contained in the original (initial) variable into a new set of dimensions or variables (factors). Data processing using the SPSS program, with the following results:

Factor Analysis

Table 3. KMO and Bartlett's Test

\begin{tabular}{llr}
\hline Kaiser-Meyer-Olkin Measure of Sampling Adequacy. & .781 \\
Bartlett's Test of Sphericity & Approx. Chi-Square & 206.443 \\
& df & 10 \\
& Sig. & .000 \\
\hline
\end{tabular}

The method used in this factor analysis is the Main Component method. From the KMO and Bartlett's Test table, the Kaiser Mayer Olkin (KMO) value of 0.781 is obtained where the value is greater than 0.5 . This value indicates the data is valid for further analysis with factor analysis. Barlet test value of 206,443 with a significant value of 0,000 below 5\%, then the correlation matrix formed is the identity matrix, or in other words, the factor model used is good. Next to see which variables have communalities values above or below 0.5 or above $50 \%$ can be seen in the following commonalities table.

Table 4. Communalities

\begin{tabular}{lrr}
\hline & \multicolumn{1}{c}{ Initial } & \multicolumn{1}{c}{ Extraction } \\
\hline Labor Force & 1.000 & .989 \\
Employment Opportunity & 1.000 & .994 \\
Level of education & 1.000 & .948 \\
Job status & 1.000 & .972 \\
Open Unemployment Rate & 1.000 & .934 \\
\hline
\end{tabular}

Extraction Method: Principal Component Analysis.

The results of data analysis indicate the greater the communalities of a variable, meaning the more closely related to the factors formed. The Communalities table shows the results of extraction individually. There are 5 (all) variables that have contributions that exceed 0.5 or $50 \%$. However, further feasibility must be tested with Explained variance. 
Table 5. Total Variance Explained

\begin{tabular}{|c|c|c|c|c|c|c|}
\hline \multirow{2}{*}{$\begin{array}{l}\text { Comp } \\
\text { onent }\end{array}$} & \multirow[b]{2}{*}{ Total } & \multicolumn{2}{|c|}{ Initial Eigenvalues } & \multicolumn{3}{|c|}{ Extraction Sums of Squared Loadings } \\
\hline & & $\%$ of Variance & Cumulative \% & Total & $\%$ of Variance & Cumulative $\%$ \\
\hline 1 & 4.836 & 96.728 & 96.728 & 4.836 & 96.728 & 96.728 \\
\hline 2 & .103 & 2.054 & 98.782 & & & \\
\hline 3 & .037 & .733 & 99.514 & & & \\
\hline 4 & .024 & .475 & 99.989 & & & \\
\hline 5 & .001 & .011 & 100.000 & & & \\
\hline
\end{tabular}

Extraction Method: Principal Component

\section{Analysis}

Based on the results of the total variance explained in the initial table of Eigenvalues, it is known that there is only 1 component of the variable, which is a relevant factor affecting the Industrial Workforce. Eigenvalues show the relative importance of each factor in calculating the variance to the five factors analyzed. From the table above, it appears that there is only 1 factor formed. Because only one factor has a total value of eigenvalues above 1 , that is, $=4,836$ for factor 1 . This shows that one factor is best for summarizing these five variables, so the factoring process stops at just one factor that will participate in further analysis.

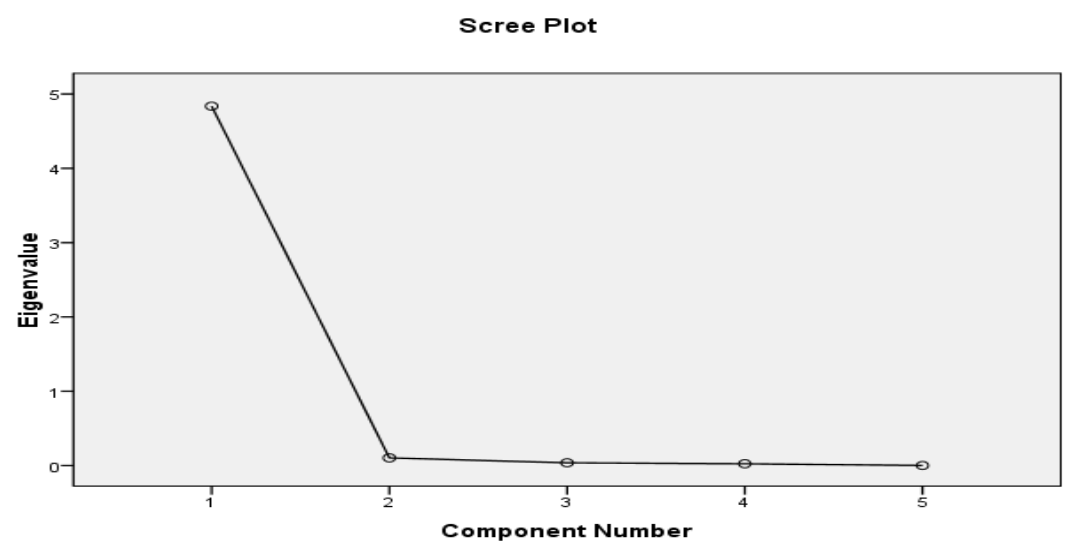

Fig. 3 S-Plot of Data Analysis

From the scree plot image above, it appears that factor 1 is above number 1 , then factor 1 to 2 in the direction of the graph decreases sharply but is already below number 1 . This shows that 1 factor is the best for summarizing the five factors. 
Table 6. Component Matrix ${ }^{a}$

\begin{tabular}{lc}
\hline & $\begin{array}{c}\text { Component } \\
\end{array}$ \\
\hline Workforce & 1 \\
Employment & .995 \\
Opportunity & .997 \\
Level of education & .974 \\
Job status & .986 \\
Open Unemployment & -.966 \\
Rate & \\
\hline
\end{tabular}

\section{Discussion}

Analysis of Confirmatory Factor Analysis Results (CFA)

The results of the confirmatory factor analysis (CFA) test revealed that the KMO value and Bartlett's test value showed that the correlation matrix formed was an identity matrix; in other words, the model factor used was good. Furthermore, the commonalities table shows the extraction results individually; there are 5 (five) variables that have a contribution exceeding 50\%, namely the Labor Force, Job Opportunities, Education Level, Employment Status, Open Unemployment Rate.

After knowing that 1 factor is the most optimal number, it can be seen in the Component Matrix table showing the distribution of the five variables on 1 factor formed. While the figures in the table are factor loadings, which show the correlation between variables with factor 1 . The process of determining which variables are most relevant to influencing the Industrial Workforce is done by comparing the large correlations of each factor. In the component matrix table shows correlations above 0.5 , there are four factors, namely:

1) Job Opportunities

2) Labor Force

3) Job Status

4) Education Level

The results of the confirmatory factor analysis (CFA) test revealed that the KMO value and Bartlett's test value showed that the correlation matrix formed was an identity matrix; in other words, the model factor used was good. Furthermore, the commonalities table shows the extraction results individually; there are five variables that have a contribution exceeding 50\%, namely the labor force, employment opportunities, education level, employment status, and unemployment rate.

Based on the results of the total variance explained in the initial table of Eigenvalues, it is known that there is only one component of the variable, which is a relevant factor affecting the Industrial Labor. Eigenvalues show the relative importance of each factor in calculating the variance to the five factors analyzed. From the table above, it can be seen that there is only 1 factor formed because only one factor has a total value of eigenvalues above one that is, $=4,836$ for factor 1 . This shows that one factor is best for summarizing the five 
variables, so the factoring process stops at just one factor that will participate in further analysis.

After knowing that the factor is the most optimal number, then in the Component Matrix table shows the distribution of the five variables on the formed factor shows the correlation between variables with the Labor Force factor. The component matrix table shows correlations above 0.5 in employment, labor force, employment status and education level.

Furthermore, after the Rotation or Rotation factor process is carried out on the formed factor which aims to clarify the variables that enter into certain factors in the Rotated Component Matrix table the Rotation Component Matrix shows a clearer and more real distribution of variables. It appears that the loading factor that used to be smaller is getting smaller and the large loading factor is getting bigger. Based on the results of the component matrix values, it is known that of the five factors, what is feasible to influence industrial labor is the workforce factor.

Thus the results of the Confirmatory Factor Analysis which aims to find a way to summarize the information contained in the original variables, namely the five original variables (labor force, employment opportunity, education level, employment status, open unemployment rate) have found a new set of dimensions, namely the labor force. This means that of the five initial variables relevant to influencing the workforce is the workforce. Manpower is a workforce, which means a country with a good workforce also has a good workforce.

By increasing the income of the labor industry, a company has an important role in choosing the labor that it needs through the workforce, employment opportunities, the level of education of the workforce, the employment status of a workforce and the level of unemployment is also very important in increasing an industry's income.

\section{Conclusion and Suggestion}

\section{Conclusion}

Based on the results of the analysis previously stated, it can be concluded, After passing a series of tests from the CFA testing process it can be seen that from the five components of the variable it is known that there is only one variable component that is an influencing factor, which because these factors have a total value of the eigenvalues above 1 . Thus the results of the Confirmatory Factor Analysis which aim to find a way to summarize the information contained in the original variables namely the five original variables (labor force, employment opportunity, education level, employment status, and unemployment rate) have found a new set of dimensions namely labor force. This means that of the five initial variables relevant to increasing industry income is the Labor Force.

\section{Suggestion}

Seen from the results of the CFA that the workforce has the best influence of the five other variable components of the Industrial workforce, it means that the government should be able to further promote the labor force program in increasing revenue for industrial companies in Indonesia so that it will be able to raise the opinion of a company. And this will improve the welfare of a company's labor force. 


\section{References}

[1] Aprilia, W., Sudarti, \& Hadi, S. Analisis Ketimpangan Penyerapan Tenaga Kerja Sektor Industri Pengolahan di Kabupaten/Kota Jawa Timur. Jurnal Ekonomi Pembangunan, 14(2), 178-188. (2016).

[2] Mahyudin, Industri dan Orientasi Eksport, universitas muhamadiyah Surakarta, Surakarta (2014)

[3] Wihana Kirana Jaya, Ekonomi Industri edisi 2, UGM, Yogyakarta, (2008).

[4] Arsyad Lincolin dan Stephanus Eri Kusuma, Ekonomi Industri, UPP STIM YKPN, Yogyakarta, (2014).

[5] Ekananda Mahyus, Ekonometrika dasar Edisi 2, Mitra Wacana Media, Jakarta, (2019).

[6] Ekananda Mahyus, Analisis Ekonometrika Time Seris Edisi 2, Mitra Wacana Media, Jakarta, (2016).

[7] Badan Pusat Statistik. Modul 8 Ketenagakerjaan. Jakarta: Badan Pusat Statistik, (2018). 